\title{
A new species of the genus Paralomis (Crustacea: Decapoda: Lithodidae) from the Spiess seamount near Bouvet Island (Southern Ocean), with notes on habitat and ecology
}

Received: 19 April 2005/ Revised: 20 October 2005/ Accepted: 4 November 2005 / Published online: 15 December 2005

(C) Springer-Verlag 2005

\begin{abstract}
A new species of the genus Paralomis, Paralomis elongata, has been collected from the Spiess seamount near Bouvet Island in the Southern Ocean. The species shows close affinity with $P$. anamerae Macpherson, 1988, from the Patagonian Shelf, P. africana Macpherson, 1987, from the south-western African shelf, and $P$. aculeata Henderson, 1888, from Crozet Islands. Morphological differences among the species and ecological characteristics are discussed.
\end{abstract}

\section{Introduction}

The Lithodidae, an anomuran family of crab-like decapods, appears to be rather diverse in shelf and upper slope waters of all oceans except the North Polar Ocean and the high Antarctic continental shelves (Zaklan 2002; Thatje and Arntz 2004). The largest generic and species diversity has been recorded in the North Pacific

\section{Spiridonov}

Zoological Museum of Moscow State University,

Bolshaya Nikitskaya 6, 103006 Moscow, Russia

M. Türkay

Forschungsinstitut Senckenberg, Senckenberganlage 25,

60325 Frankfurt a. M., Germany

W. E. Arntz

Alfred Wegener Institute for Polar and Marine Research,

Columbusstraße, 27568 Bremerhaven, Germany

S. Thatje

National Oceanography Centre, Southampton,

School of Ocean and Earth Science, European Way,

SO14 3ZH Southampton, UK

Present address: V. Spiridonov $(\square)$

Laboratory of Coastal Ecosystems,

P.P. Shirshov Institute of Oceanology of the Russian Academy

of Sciences, Nakhimov Avenue, 36, 117997 Moscow, Russia

E-mail: vspiridonov@wwf.ru
(Makarov 1938; Dawson and Yaldwyn 1985; Dawson 1989; Zaklan 2002).

In Subantarctic and Antarctic waters, a number of lithodid species were discovered through increasing sampling efforts in the past years (Arntz and Thatje 2004; Thatje et al. 2005). It is remarkable that most of them occur on insular shelves and slopes including the Falkland shelf, Burdwood Bank, South Georgia (Birstein and Vinogradov 1972; Macpherson 1988a), Prince Edward Islands (Henderson 1888), Crozet and Possession Islands (Arnaud 1971, 1976), Scott Island (Birstein and Vinogradov 1967; Macpherson 1988b), but remain completely absent from the high-Antarctic continental shelves due to physiological constraints imposing on biogeography (Thatje 2004, Thatje and Arntz 2004). The expeditions EPOS and ANT XXI with R/V "Polarstern" explored the benthic environment of Spiess Seamount close to Bouvet Island. The trawl sampling during these expeditions resulted in the collection of several specimens of Lithodidae, which not only close a biogeographic gap, but which are also belonging to a new species. In this paper we describe this new species obtained from Agassiz trawl and stone sledge samples. Underwater photography revealed that the top of the Spiess Seamount is characterised by volcanic rock, with almost no layer of finer sediments (see Arntz et al. 2006). Part of the rock surface shows dense accumulations of spines of regular sea urchins, which also appeared in the AGT samples. The benthos is poor of species and characterised by very abundant ophiuroids, a few anthozoans and polychaetes (Arntz et al. 2006).

The Paralomis material is deposited in the Research Institute and Museum Senckenberg (SMF), catalogue numbers apply to the collections of the Senckenberg Museum. For taxonomic study, comparative material on related species was examined from the collections of The Natural History Museum, London (NHM) and the Zoological Museum of Moscow State University (ZMMU).

The following abbreviations are used for the measurements: $\mathrm{CL}=$ carapace length (measured from the 
base of the rostrum on the orbit side to the posterior margin of the carapace); $\mathrm{CW}=$ maximum carapace width; P2-4 = pereopods $2-4 ; \mathrm{ML}=$ length of merus measured along dorsal margin; $\mathrm{MW}=$ maximum width of merus; $\mathrm{CaL}=$ carpus length measured along the dorsal margin; $\mathrm{CaW}=$ maximum width of the carpus; $\mathrm{PL}=$ propodus length measured along dorsal margin; DL = dactylus length measured along dorsal margin; $\mathrm{ChL}=$ chela length measured along dorsal margin; $\mathrm{ChH}=$ maximum chela height; ChT = maximum chela thickness.

\section{Systematics}

Paralomis elongata Spiridonov, Türkay, Arntz, Thatje n. sp. (Figs. 1, 2, 3, 4, 5)

Holotype 1 male (SMF 30111), Spiess Seamount, R/V "Polarstern" EPOS 3 Expedition, March 1989, St. 312, Haul 27, 320 m, Agassiz Trawl (Figs. 1, 2, 3, 4).

Paratypes 1 male, 1 ovig female (SMF 30112), Spiess Seamount, R/V "Polarstern", ANT XXI (2), St. 65-3441, 54 44,4'S, $00808,13^{\prime} \mathrm{E}$, ca. 300 m, Agassiz Trawl (for details see Arntz and Brey 2005).

Diagnosis Carapace rounded, generally pyriform, somewhat longer than broad. Postorbital area bears four to five spinules. Largest sharp granule occupying the highest level of the gastric area, a pair of similar granules on the posterolateral area and three similar granules on the intestinal area, and the remaining dorsal carapace surface densely covered with smaller granules. Rostrum consisting of basal (ventral) and two long dorsal spines overreaching the cornea and two pairs of additional spinules posterior to the dorsal ones, the median pair being smaller and barely distinguishable in smaller size specimens. External orbital spine hardly reaching the cornea. Antero-lateral and lateral margin with six to seven large setose spines and smaller spinules between them. Postero-lateral and posterior border with 15-16 sharp setose spines and spinules. Marginal plate of the abdominal segment $\mathrm{V}$ armed with three large setose teeth. Scaphocerite with two large mesial subequal spines directed dorsally; two long black-tipped terminal spines and a large lateral spine; without granules. Walking legs are relatively slender and more than twice as long as the carapace. Merus of $\mathrm{P} 3$ reaches more than $70 \%$ of the CL. All spines on meri of pereopods two to four separated, those on posterior face, totaling more than ten strong spines in two rows.

Description of male holotype (Figs. 1, 2, 3, 4) Carapace rounded, generally pyriform, somewhat longer than broad. Areas well-defined, gastric area elevated, cardiac area forms a triangle. Postorbital area sloping down laterally, bearing four to five spinules. Dorsal surface of the carapace densely covered mostly with acute granules and generally flatter ones on the gastric area (except of the granule occupying the highest level of it, which is acute and larger than the others). Besides the largest gastric granule, another pair of larger granules with tufts of setae is located at the highest level of the branchial areas; a pair of similar granules is located close to the junction at each postero-lateral border with the posterior margin; the intestinal area bears three similarly shaped large granules.

Subhepatic and pterygostomial areas with rare inconspicuous granules, nearly smooth and unarmed, except for a small spine at the terminal angle of the pterygostomial area.

Basal (ventral) spine of the rostrum is curved, blacktipped, and its ventral surface is smooth. Two nearly parallel black-tipped dorsal spines with an U-shaped incision between them hardly reach the tip of the basal spine. Basal and dorsal spines overreach the cornea. Two pairs of smaller spines posterior to dorsal ones are arranged in a nearly straight line, the lateral ones being somewhat larger than medians.

External orbital spines are long and sharp and hardly reach the cornea. Anterior margin of the carapace slightly concave with a small spine close to the first antero-lateral spine. Antero-lateral margins have four large black-tipped spines and smaller spinules between them. Lateral margin has two large black-tipped and slightly curved spines and three smaller anterior spinules, respectively. Postero-lateral margin has four to five larger setose spinules and several smaller ones behind and between them, intergrading into the similarly ornamented posterior margin; altogether these spines and spinules amount to 15-16.

Abdominal segment II is covered with granules similar to those on the posterior face of the carapace. The segment is entire without separation into plates and only the lateral parts are separated by depressions. Anterior margin has a pair of large setose spinules medially, the lateral margins have six to eight similar ones. On segment III, the median plate is separated from lateral ones by furrows, the former covered with numerous setose granules, and the latter with fewer granules, while the lateral margins are armed with five spinules. Segment IV has a similar external division into median and lateral plates, in addition to two much smaller marginal plates on either sides. Median and lateral plates nearly lack granules, but bear tufts of setae on their borders, and each marginal plate is armed with three large setose teeth. Segment V has lateral plates that are about twice as the long as median one and clearly overreach it posteriorly. Granulation and setation pattern of the median and lateral plates are similar to those of the previous segment; each marginal plate is armed with three setose teeth. Segment VI is somewhat broadened towards the telson, its periphery has tufts of setae, and the posterior margin has two spinules adjacent to the telson; the marginal plates armed with two teeth. Telson trapezoidal has a longitudinal groove and two spiniform granules. 
Fig. 1 P. elongata sp.n., holotype (SMF 30111), CL 93.5, CW 91.5. a Dorsal view. b Ventral view
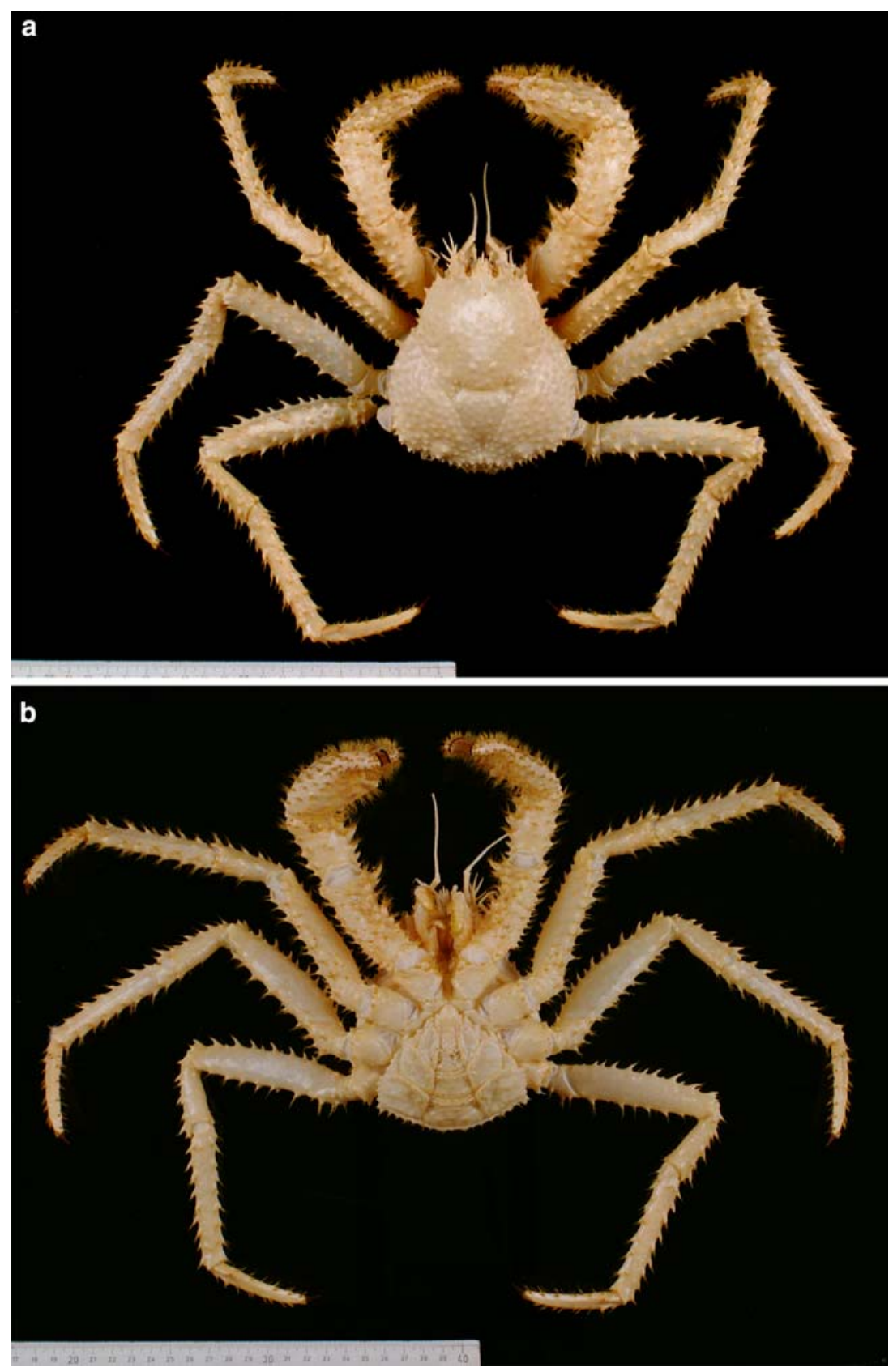

Antennular peduncles elongated, somewhat overreaching the cornea, are distinctly convex laterally and somewhat convex dorsally, the third segment is longer than the second.

Basal segment of the antennal peduncle has a small antero-external spine; the second segment has a long spine by far overreaching the spiniform termination of the last segment of the peduncle and one additional spinule at the base. Scaphocerite has a spinule at the base on both the lateral and mesial faces; mesial face further bears two subequal spines directed dorsally; two long black-tipped terminal spines and a smaller spine are on the lateral face; the surface is smooth without granules. The first segment of the antennal flagellum is stout, and the second is elongated, more than twice as long as first.
Chelipeds are unequal, the right is more massive than the left. Basipodites of the chelipeds have few, flat granules and tufts of setae on the ventral face, transition to the mesial face is densely beset with tufts of setae, the mesial and lateral faces are otherwise smooth; the ischia have two converging rows of setose tubercles on the ventral face and some on the lateral face; the mesial face has scattered tufts of setae. Meri have three rows of setose spinules on the extensor face, two rows on the flexor face and two rows on the lateral faces; some spinules are located between the rows; the mesial face has sparse tufts of setae and two strong spines near the junction to the carpus. Carpi sub-cylindrical and have six to seven rows of setose spines (on dorsal face) and setose tubercles (on inner face). Chelae have rows of 
Fig. 2 P. elongata, holotype (SMF 30111). Anterior area. a Frontal view b Dorsal view

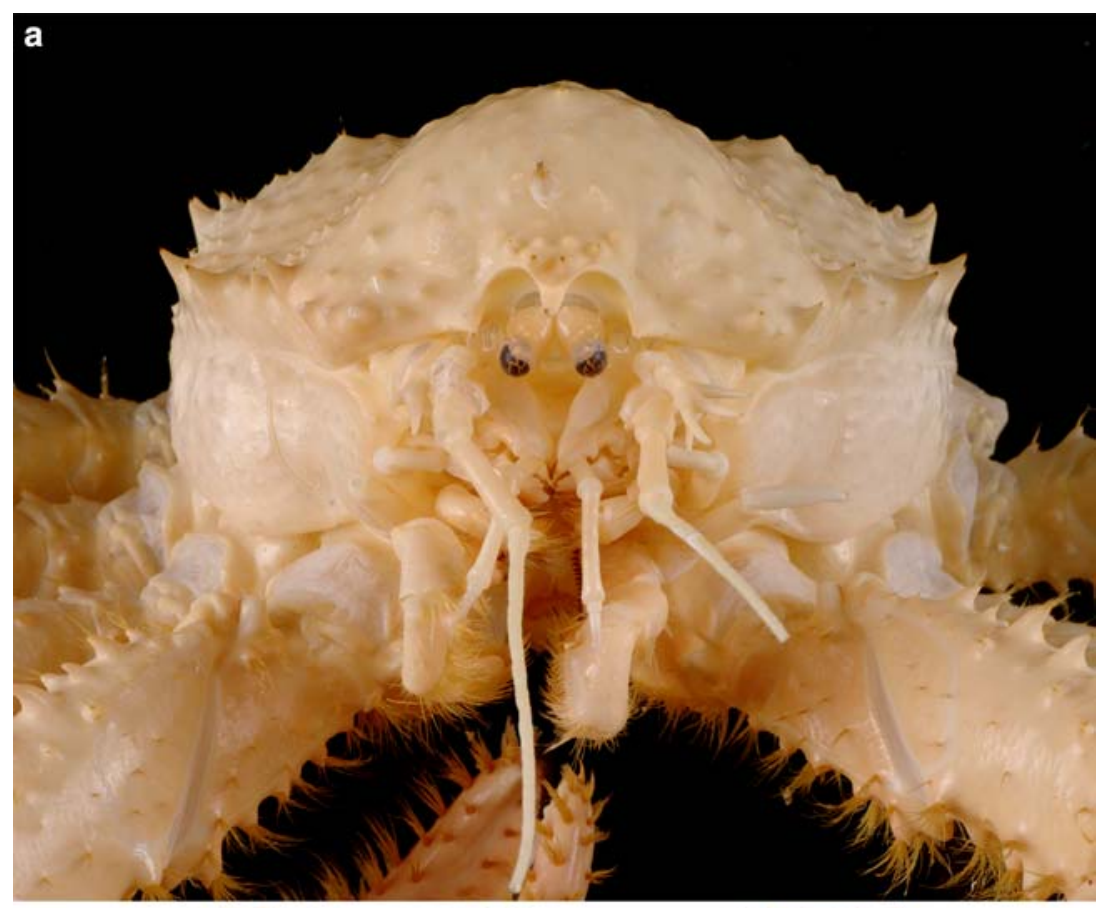

b

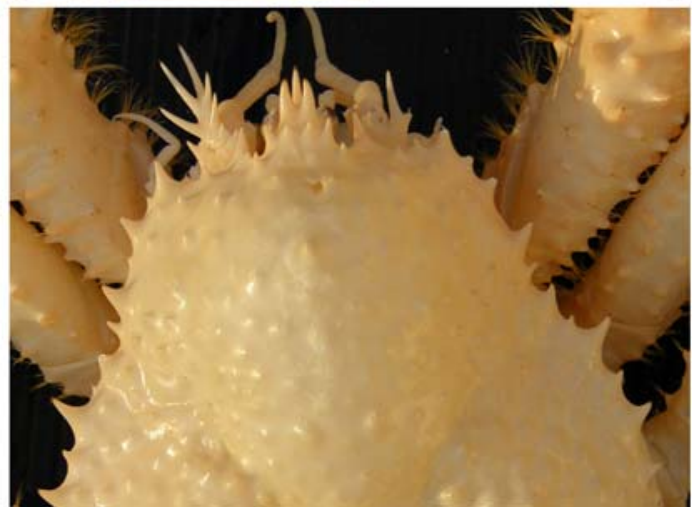

tufts of setae, proximally associated with distinct tubercles; on the dorsal face there are two irregular rows of setose spines. Fingers of larger chela with three broad proximal teeth each, are rounded on the movable finger and more truncated on the immobile one; the distal third of the cutting edge is armed with a dark (probably silicified) band, which forms an indistinct spoon-shaped face. Fingers of the smaller chela have numerous small teeth that increase in size distally and similar dark bands are seen in the distal thirds of the cutting edges.

Pereopods (P) 2-4 are relatively slender, similar in size and morphology, P 3 is somewhat longer than the others, more than twice as long as the carapace. Basipodites of pereopods are generally smooth with tufts of setae on the flexor faces. Meri are sub-cylindrical: the extensor face has a row of ca. 12 black-tipped spines, the flexor face has two rows consisting of five to seven black-tipped setose spines and two to three spines between them. The anterior face is generally smooth, with sparse tufts of setae and indistinct granules. The posterior face has two arquate rows of spines, most being black-tipped and setose: in P3 with ten spines in the upper row and six spines in the lower one, in P4 with eight to nine spines in the upper row and four spines in the lower one. Carpi are sub-cylindrical, with two rows of six to seven black-tipped setose spines on the extensor face, four to five spines on the posterior face and a row of three to four spines in the upper part of the anterior face; the remaining surface is smooth. Propodi are compressed laterally, with two to three irregular rows of five to eight black-tipped setose granules on both the extensor and flexor faces, with an irregular row of somewhat smaller spinules on the posterior face, and generally smooth with scattered setose tubercles on the anterior face. Dactyli are compressed laterally; in their proximal fourth there are two setose black-tipped spines on the extensor face, on the posterior face two ridges are terminating with setose black-tipped spines, and one ridge ends in a spine on the anterior face; irregular rows of tufts of setae border the extensor and flexor faces, this last one has a row of thin and sharp dark spines, which increase in length distally; the remaining posterior and anterior surfaces are smooth. 
Fig. 3 P. elongata, holotype (SMF 30111). a Posterior area, caudal view. b Abdomen
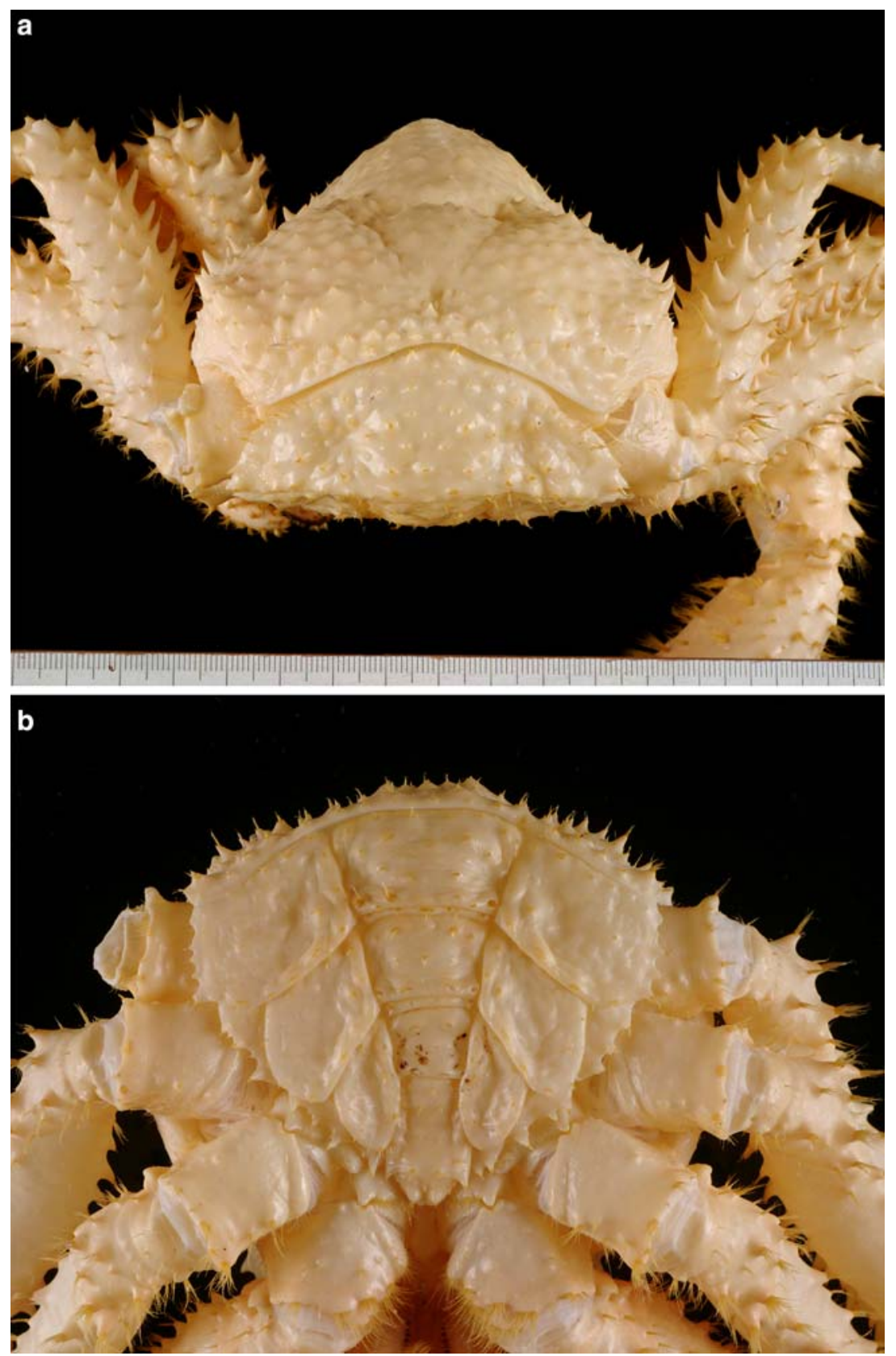

Female characteristics and variation The abdomen of an ovigerous female is asymmetric (Fig. 5b). The asymmetry is nearly not expressed in segment II, which has a granulation and spinulation pattern similar to that of the male holotype. In the following segments the left side the lateral plates are broader and longer than those on the right side. The marginal plates on the left side are not separated from the lateral ones, their margins in segments III-V are denticulated; denticles increase in size from segment IV-V. On the right side, the marginal plates are separated from the lateral plates in segments III-V; there are four setose teeth on the margin of segment III, three teeth on the margin of segment IV and two teeth on the margin of segment V.
The ovigerous female and a supplementary male of similar size show little differences to the holotype with regard to the carapace shape, its spinulation and granulation pattern. Their rostra lack, however, the median pair of additional rostral spinules, and the scaphocerites also are without additional proximal spines.

Size (in $\mathrm{mm}$ )

Holotype male-CL 93.5, CW 91.5; P 3: ML 81.8, MW 16.7, CaL 42.4, CaW 12.6, PL 64.0, DL 61.5; right chela: ChL 89.2, ChH 35.6, ChT 25.7, DL 45.6.

Ovigerous female - CL 50.0, CW 45.4; P 3; ML 35.1, MW 8.1, CaL 20.8, CaW 5.2, PL 28.1, DL 24.9.

Male-CL 47.5, CW 43.8, P 3: ML 35.1, MW 8.8, CaL 18.1, CaW 6.2, PL 8.6, DL 24.0. 

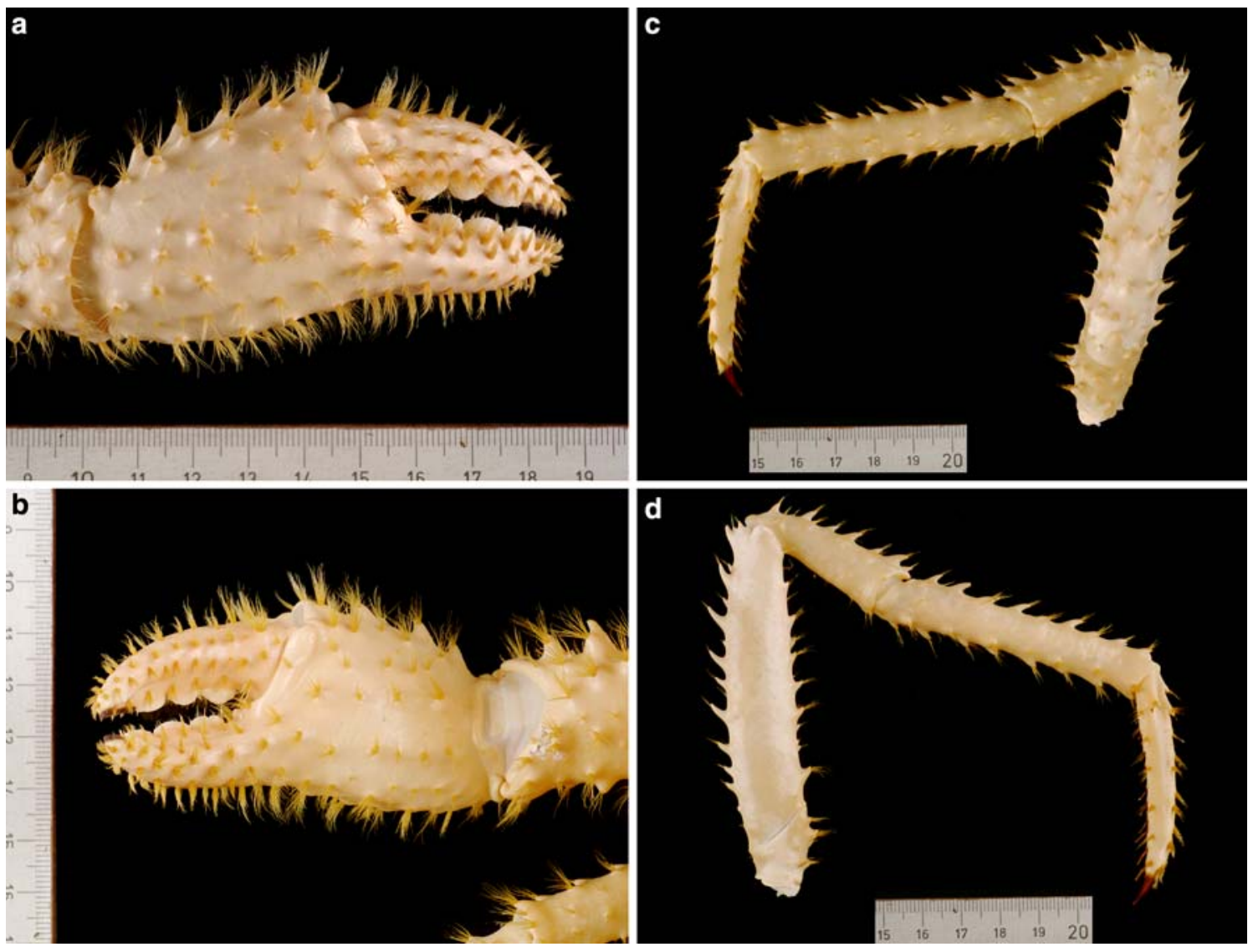

Fig. 4 Paralomis elongata. Holotype (SMF 30111). a Right (larger) chela, outer view, b Right (larger) chela, inner view. c Pereopod 4 , anterior view. d Pereopod 4, posterior view

Colouration According to underwater colour photographs (see Arntz et al. 2006) and the photo taken on deck on freshly caught animals, rostrum, anterior margin of carapace, cardiac area, large spines on carapace, bases of granules, and scaphocerites are pink, the background colouration is pink-orange, while in the underwater photo it is yellowish. Chelipeds and walking legs are red with the fingers brick red, setae on the pereopods are golden yellow. This colouration largely retains after 8 months preservation in formalin. Abdomen (seen only on preserved specimens) is whitish, with bases of spinules pink.

Etymology The species was named after its elongate carapace and relatively long legs.

Affinities The new species is most similar to the South Atlantic Paralomis anamerae Macpherson, 1987, described from the Patagonian Shelf, P. africana Macpherson, 1982 described from the Namibian Slope and to P. aculeata Henderson, 1888 from Prince-Edward Island (Indian Ocean Subantarctic). While the two species described by E. Macpherson have been sufficiently illustrated, Henderson's $P$. aculeata has to date only been known from the "Challenger" report figures. Therefore, we are giving new illustrations of the single type specimen of this species. According to the Paragraph 73.1.2. of the International Code of Zoological Nomenclature (ICZN 1999, p. 79) this single specimen has to be considered as a holotype by monotypy. All mentioned and closely related species share such characteristics as the shape of the rostrum and the general shape of scaphocerite, granulation and spinulation pattern of the carapace and pereopods. They may be distinguished by the characteristics listed in Table 1 . The differences between the new species and $P$. anamerae and especially $P$. aculeata are small but stable throughout several specimens. The male holotype of $P$. aculeata is a juvenile animal somewhat smaller than the smallest male of $P$. elongata from our collection. They are in most respects similar, but $P$. aculeata has a reasonably large unpaired dorsal median spinule on the rostrum and the less developed mesial spines on the scaphocerite. The pattern of dorsal spinulation appears to have a high diagnostic value for defining species of Paralomis, which either have or lack the median rostral spinule (Macpherson 1988a) (Fig. 6).

The present species differs in several characters from $P$. anamerae, most important being the spinulation pattern and the relative length of pereopod meri. The length of the $\mathrm{P} 3$ merus to $\mathrm{CL}$ ratio varies but it is markedly greater (more than 0.7 of CL) in P. elongata 
Fig. 5 P. elongata, female paratype (SMF 30112), CL 50.0, CW 45.4. a Dorsal view. b Abdomen
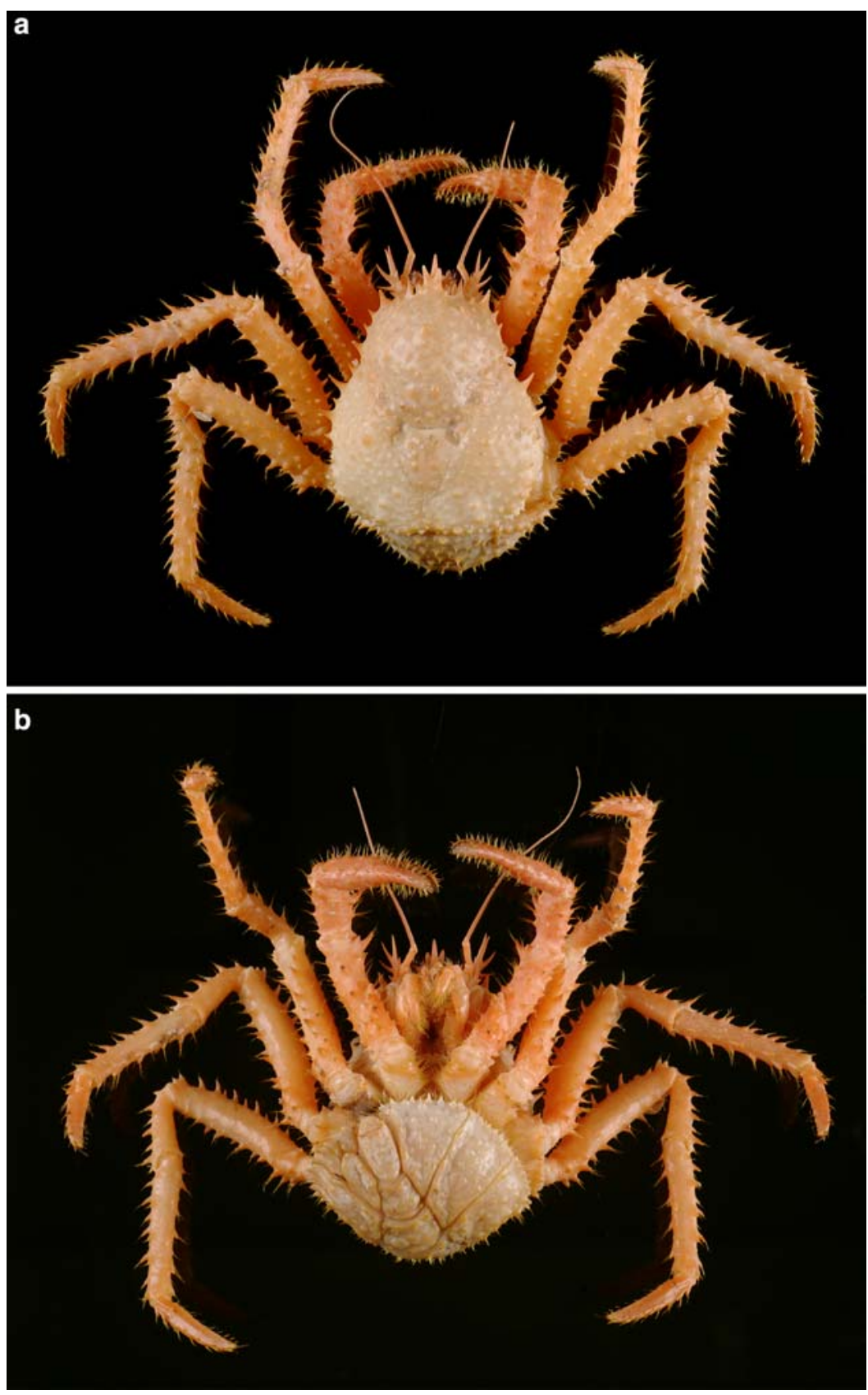

than in $P$. anamerae (about 0.6). Also the posterior face of meri in P3-P4 of the new species bears a lesser number of spines (13-17 arranged in two rows versus 78 forming one row in P3 and 12-14 versus 10-11 spines in P4). Although the variation of the P3 merus to carapace length ratio needs further analysis, using data of statistically representative samples, which are not available now, it appears to have a high diagnostic value for distinguishing between all four closely related species (Table 1). Furthermore, the dorsal spinules of the rostrum are aligned in $P$. elongata, while those in $P$. anamerae are in two rows but Macpherson's (1988a) pl. 28B and Fig. 53A show differences from one side to the other.
Habitat and symbionths The underwater photography (see Arntz et al. 2006) accompanying the sampling of lithodids, revealed that the Spiess Seamount is characterised by volcanic rock and lacks fine sediments. The benthos both on the underwater imagery and in the trawl samples was extremely poor. The AGT samples consisted of the few Paralomis specimens, smashed but big regular seaurchins, and occasionally ophiuroids and big anthozoans were found on the pieces of lava coming up with the gear.

The male paratype carries numerous lepadomorphs that has overgrown the pereopods and the frontal area of the carapace. 
Notes on the lithodid distribution in the Antarctic and Subantarctic

Together with $P$. elongata the Subantractic and Antarctic fauna of the Lithodidae includes 11 species of three genera (Macpherson 2004; Thatje and Arntz 2004; Thatje and Lörz 2005). In the Western Atlantic sector, the lithodid fauna is most diverse and includes two groups of species showing different distribution pattern. The first group widely occurs along the Pacific slope of South America and ranges to the Subantarctic and Antarctic Islands of the West Atlantic and the East Pacific sector. It includes Neolithodes diomedeae (Benedict 1894) occurring on the Falkland shelf and in the South Georgia area and Lithodes turkayi Macpherson, 1988, reaching the Falkland shelf and slope and recorded at Peter 1st Island in the Bellingshausen Sea. The second group combines the species distributed around the southern termination of South America and along the south-eastern shelf and slope of South America. These are Lithodes confudens Macpherson, 1988, which reaches the Falkland Shelf, L. santolla (Molina 1782) also occurring on the Falkland shelf, Paralomis formosa Henderson, 1888, extending as far as to South Georgia and South Orkney Islands, $P$. granulosa (Jacquinot 1852) occurring on the Falkland shelf, and P. spinosissima Birstein and Vinogradov, 1972, ranging from the Patagonian shelf to the South Georgia shelf and slope.

The fauna of the East Atlantic and the Indian sector of the Antarctic and Subantarctic does not include the species known from the islands of the West Atlantic and the East Pacific sectors. Two closely related species $P$. elongata and $P$. aculeata occur on the peaks of the southern termination of the Mid-Atlantic Ridge and the western outreach of the Western Indian Ridge, respectively. These species differ in many characteristics from the Paralomis species occurring around the southern part of South America and off the islands of the West Atlantic sector of the Antarctic, but they show clear affinities to the species known from northern Patagonian shelf ( $P$. anamerae) and the SW-African Slope ( $P$. africana). Recently, $P$. anamerae has been recorded also on the Lena and Ob' bank (Macpherson 2004). However, the material from this area, which is of our disposal in the Zoological Institute of Russian Academy of Sciences in St. Petersburg indicates that this may be closely related to P. anamerae but yet a different species. Besides this Neolithodes duhameli Macpherson, 2004 has been recently described from the deep waters off Crozet Islands while P. birsteini Macpherson, 1988 has been found in the Crozet Islands and the Kerguelen Islands area (Macpherson 2004).

The lithodid fauna is again different further east of those islands. Lithodes murrayi Henderson, 1888, widely ranges at shelf depth in an area including the Mozambique Channel, Prince Edward Islands, Crozet and Possession Islands, as well as off Macquarie Islands and southern New Zealand (Macpherson 1988a). P. birsteini Macpherson, 1988, is known from the Balleny and Scott 
Fig. 6 P. aculeata Henderson, 1888, male holotype (NHM 88.33), CL $42.0 \mathrm{~mm}, \mathrm{CW}$ $39.0 \mathrm{~mm}$. a Dorsal view. b Ventral view
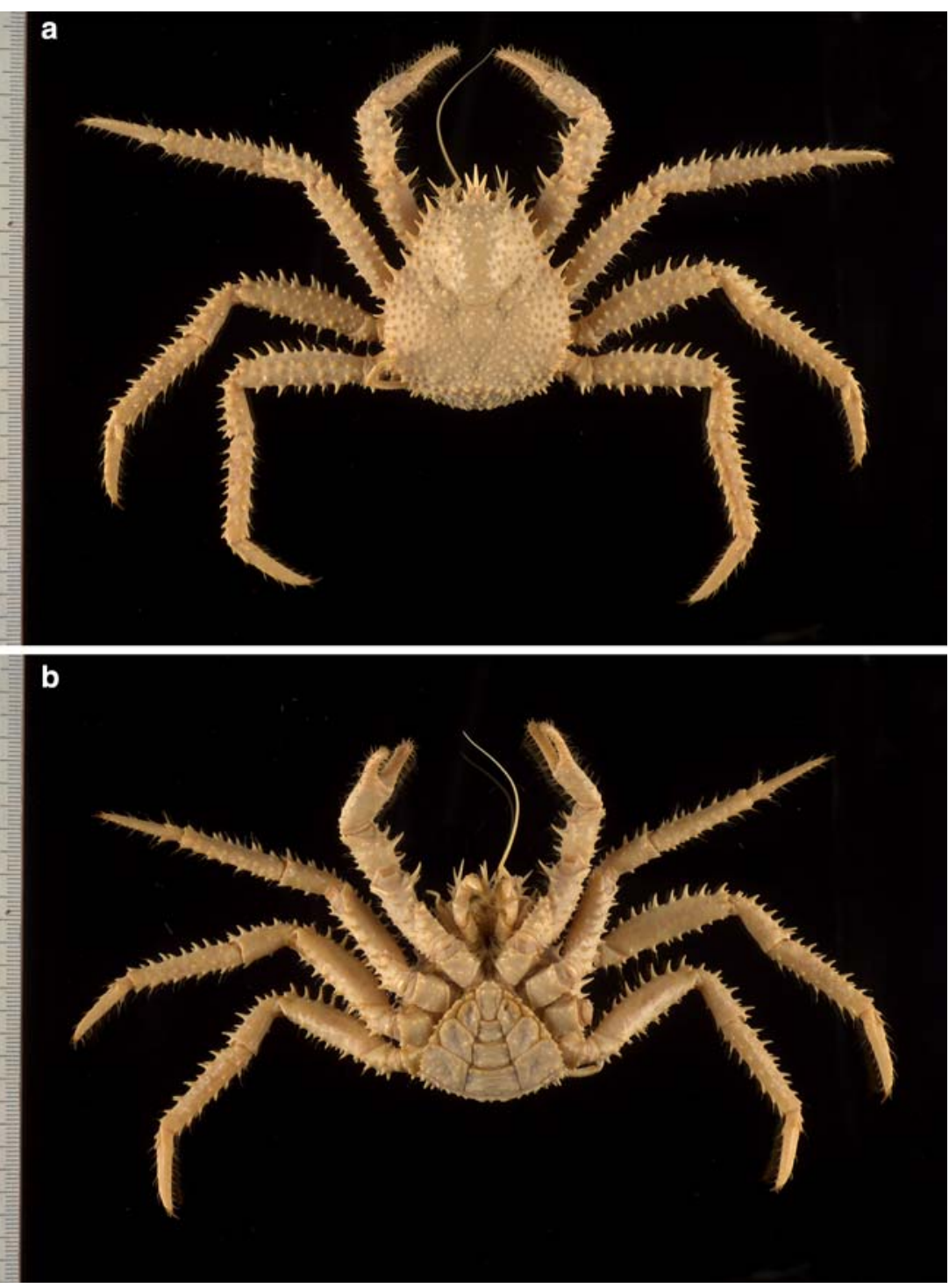

Island area (Thatje and Arntz 2004, also unpublished record based on the collections of the Zoological Institute, St. Petersburg), Peter 1 Islands (Arana and Retamal 1999). The second together with more eastward records of $P$. birsteini near the Antarctic Peninsula and the South Orkney Islands (Arana and Retamal 1999) need to be checked in order to be sure that there is no confusion with the related species $P$. formosa.

This summary of the distribution shows that there is not a single Antarctic-Subantarctic homogeneous lithodid fauna, but the species assemblages change from west to east around the area. Within the genera as represented in the individual regions, however, there may be closely related species as exemplified by the group containing $P$. anamerae, $P$. elongata and $P$. aculeata.

Acknowledgements We are indebted to the captain and crew of RV Polarstern for assistance at sea and the Norwegian government for the sampling permit for waters off Bouvet Island. Our gratitude also extends to Paul Clark (NHM, London) for providing the holotype of Paralomis aculeate for examination and to Kristin Pietratus
(SMF) for technical assistance during the work with collections. We furthermore thank two anonymous referees for their valuable comments on the manuscript. The work of VAS in the collections of the Research Institute and Museum Senckenberg, Frankfurt on Main (SMF), was made possible through an Alexander von Humboldt fellowship in 1994-1996 and the visiting scientists grants provided by the Senkenbergische Naturforschende Gesellschaft.

\section{References}

Arana PM, Retamal MA (1999) Nueva distribucion de Paralomis birsteini Macpherson, 1988en aquas antarticas (Anomura, Lithodidae, Lithodinae). Invest Mar Valparaiso 27:101-110

Arnaud PM (1971) Lithodes murayi Henderson, 1888 (Crustacea, Decapoda, Anomura) dans les eaux côtières dans Îles Crozet (SW del Ocèan Indien). Thetys 3:167-172

Arnaud PM (1976) Pêches experimentale de Lithodes murrayi Henderson, 1888 (Crustacea, Anomura) aux îles Crozet (SW del Ocèan Indien). CNFRA 39:27-35

Arntz WE, Brey T (eds) (2005) The expedition ANTARKTIS XXI 2 (BENDEX) of RV Polarstern in 2003/2004. Ber Polarfosch Meeresforsch (Rep Polar Mar Res) 503:1-149 
Arntz WE, Thatje S, Linse K, Avila C, Ballesteros M, Barnes DKA, Cope T, Cristóbo Rodríguez FJ, De Broyer C, Gutt J, Isla E, López-González P, Montiel A, Munilla T, Ramos Esplá AA, Raupach M, Rauschert M, Rodríguez E, Teixidó T (2006) Missing link in the Southern Ocean: sampling the marine benthic fauna of remote Bouvet Island. Polar Biol (in press)

Birstein YA, Vinogradov LG (1967) Occurrence of Paralomis spectabilis Hansen (Crustacea, Decapoda, Anomura) in the Antarctic. In: Exploration of the fauna of the sea. IV (XII). Biological Results of the Soviet Antarctic Expedition (in Russian, available also in the Publication of Israel Programme for Scientifuc Translation), vol 3, pp 390-398

Birstein YaA, Vinogradov LG (1972) Lithodid crustaceans (Decapoda, Anomura, Lithodidae) of the Atlantic sector of the Antarctic, South America and South Africa (in Russian). Zool Z 51:351-363

Dawson EW (1989) King crabs of the world (Crustacea: Lithodidae) and their fisheries. A comprehensive bibliography. New Zealand Oceanological Inst Misc Publ 101:338

Dawson EW, Yaldwyn JC (1985) Kings crabs of the world or the world of king crabs: an overview of identity and distribution - with illustrated diagnostic keys to the genera of the Lithodidae and to the species of Lithodes. In: Proceedings of the international King Crab symposium, January 1985, Anchorage, Alaska, Alaska Sea Grant Report 85, pp 69-106

Henderson JR (1888) Report on the Anomura collected by H.M.S. Challenger during the years 1873-76. Reports on scientific research of the voyage of H.M.S. Challenger. Zoology,vol 27, pp I-vii, $1-221$

ICZN - International Commission of Zoological Nomenclature (1999) International code of zoological nomenclature, 4th edn, $306 \mathrm{p}$
Macpherson E (1988a) Revision of the family Lithodidae Samoelle, 1819 (Crustacea, Decapoda, Anomura) in the Atlantic Ocean. Monogr Zoologia Marina 2:1-153

Macpherson E (1988b) Three new species of Paralomis (Crustacea, Decapoda, Anomura, Lithodidae) from the Pacific and the Antarctic Oceans. Zool Scripta 17:69-75

Macpherson E (2004) A new species and new records of lithodid crabs (Crustacea: Decapoda: Lithodidae) from the Crozet and Kerguelen Islands area (Subantarctica). Polar Biol 27:418-422

Makarov VV (1938) Fauna of USSR. Crustacea, vol 10 (3). Anomura (in Russian with extended English summary) Publishing House of the Academy of Sciences of USSR, Leningrad, $324 \mathrm{pp}, 5 \mathrm{pls}$

Thatje S (2004) Reproductive trade-offs in benthic decapod crustaceans of high southern latitudes: tolerance of cold and food limitation. Berichte Polar Meeresforsch (Rep Polar Mar Res) 483:1-183

Thatje S, Arntz WE (2004) Antarctic reptant decapods: more than a myth? Polar Biol 27:195-201

Thatje S, Lörz AN (2005) First record of lithodid crabs from Antarctic waters off the Balleny Islands. Polar Biol 28:334-337

Thatje S, Anger K, Calcagno JA, Lovrich GA, Pörtner HO, Arntz WE (2005) Challenging the cold: crabs reconquer the Antarctic. Ecology 86(3):619-625

Zaklan SD (2002) Review of the family Lithodidae (Crustacea: Anomura: Paguroidea): Distribution, biology, and fisheries. In: Paul AJ, Dawe EG, Elner R, Jamieson GS, Kruse GH, Otto RS, Sainte-Marie B, Shirley TC, Woodby D (eds) Crabs in cold water regions: biology, management, and economics. University of Alaska Sea Grant College Program AK-SG-02-01, Fairbanks, pp 751-845 